\title{
Occurrence of microcystins along the Guadiana estuary
}

\author{
Cristina Sobrino ${ }^{1}$, Alexandre Matthiensen, Susana Vidal \& Helena Galvão
}

Centro de Investigação Marinha e Ambiental (CIMA), Universidade do Algarve Gambelas, Faro 8005-139

Portugal. (1) csobrino@ualg.pt

\begin{abstract}
Blooms of toxic cyanobacteria develop regularly during summer and early autumn in the Guadiana River (South of Iberian Peninsula). Microcystis aeruginosa, Aphanizomenon flos-aquae, Oscillatoria spp. and Anabaena spp. have been identified in previous studies as the main toxic cyanobacteria present.

With the closure of the Alqueva dam and its new policy of water retention, the present project focused on the effect of these new hydrological conditions to toxic cyanobacteria bloom formations in the Guadiana estuary.

This article shows data collected from three sampling stations located along the estuary during the spring of 2002 . Physical and chemical parameters (temperature, salinity, turbidity and nutrients (dissolved nitrate, silicate and phosphate)) and biological characteristics of the water (chlorophyll $a$ and phytoplankton composition) were evaluated, as well as microcystin (MC) content in particulate material using HPLC-PDA.

Microcystis sp. was the dominant toxic cyanobacteria in the collected water samples. Results suggest the existence of a longitudinal gradient in toxin content directly related to the development of temperature, salinity and nutritional ratio gradients along the estuary, and indirectly related to the turbidity of the water. At least five MC variants were observed and quantified as MC-LR equivalents (MC-LR Equiv.). The total MC concentrations in particulate material varied from 0.0 to above $1.0 \mu \mathrm{g}$ MCLR Equiv. $\mathrm{L}^{-1}$, with higher values always observed at the freshwater station.

Finally, higher dissolved silica concentrations were found in the water column when compared to results from previous years. These differences reflect changes in the Guadiana ecohydrological status which are probably related to the Alqueva dam construction.
\end{abstract}

Keywords: Guadiana River, estuaries, microcystins, Alqueva dam.

\section{RESUMEN}

La formación de blooms de cianobacterias tóxicas se produce regularmente durante los meses de verano y principios del otoño en el Río Guadiana (Sur de la Península Ibérica). Entre las diferentes cianobacterias potencialmente tóxicas estudios previos han identificado a especies como Microcystis aeruginosa, Aphanizomenon flos-aquae, Oscillatoria spp. y Anabaena spp.

Con la puesta en funcionamiento de la presa de Alqueva y su nueva política de retención de aguas, se elaboró el presente proyecto enfocado hacia el estudio del efecto de las nuevas condiciones hidrológicas sobre la formación de blooms de cianobacterias tóxicas en el estuario del Guadiana.

Este artículo muestra los datos obtenidos en tres estaciones de muestreo localizadas a lo largo del estuario del Guadiana durante la primavera del año 2002. Se analizaron parámetros físico-químicos (temperatura, salinidad, turbidez y nutrientes (nitrato, silicato y fosfato disueltos)) y características biológicas del agua (clorofila a y composición fitoplanctónica), así como el contenido de microcistina (MC) en el material particulado cuantificado por HPLC-PDA, en tres estaciones de muestreo situadas a lo largo del estuario.

Microcystis sp. fue la cianobacteria tóxica predominante en las muestras de agua analizadas. Los resultados sugieren la existencia de un gradiente longitudinal en el contenido de toxinas directamente relacionado con el desarrollo de gradientes longitudinales de temperatura, salinidad y cocientes nutricionales a lo largo del estuario, e indirectamente relacionado con la turbidez del agua. Se observaron al menos cinco variantes de MC que se cuantificaron como equivalentes de MC-LR (Equiv. $M C-L R)$. La concentración total de MC en material particulado varió de 0.0 a más de $1.0 \mu g$ Equiv. $M C-L R \cdot L^{-1}$, observándose siempre los valores superiores en la estación de agua dulce.

Finalmente, fueron encontradas concentraciones de silicato disuelto en la columna de agua superiores a las de años anteriores. Estas diferencias reflejan cambios en el estado ecohidrológico del Guadiana probablemente relacionados con la construcción de la presa de Alqueva.

Palabras clave: Río Guadiana, estuarios, microcistinas, presa de Alqueva.

Limnetica 23(1-2): 133-144 (2004). DOI: 10.23818/limn.23.11

(C) Asociación Ibérica de Limnología, Madrid. Spain. ISSN: 0213-8409 


\section{INTRODUCTION}

Nowadays, the alterations derived from the human economic and social development constitutes one of the main ecological problems for river systems. There is a progressive tendency in decreasing water quality from water basins due to an increase in nutrient input (EEA, 2000) and large dam construction has proven to be one of the primary destroyers of aquatic habitats (Rosenberg, 2000). An increase in nutrient content results in higher phytoplankton production that can occasionally promote blooms of microalgae resulting in noxious water. Moreover, changes in nutrient composition, including those caused by the hydrological alterations, can influence phytoplankton composition (Officer \& Ryther, 1980; Rosemberg, 2000 and references therein), affecting simultaneously the food web (Ryther \& Officer, 1981).

The Guadiana River is located in the southwestern Iberian Peninsula, being the fourth largest drainage basin of Iberian rivers $(67840$ $\mathrm{km}^{2}$ ). The total river length is $810 \mathrm{~km}$, of which $68 \%$ belongs to Spanish territory and $32 \%$ to Portuguese territory, with a section of $110 \mathrm{~km}$ serving as the border between both countries. The study of physico-chemical parameters, as well as the biological status of the Guadiana River, is of particular importance due to the recent construction of the Alqueva dam, one of the biggest dams in the Iberian Peninsula and the largest artificial lake in Europe. This study is probably the first to measure physical chemical and biological parameters in the Guadiana estuary after the regulation of water flow began in February 2002.

Cyanobacteria blooms have occurred regularly in the Guadiana River (Cabeçadas \& Brogueira, 1981; Oliveira, 1985; Vasconcelos et al., 1996; Rocha et al., 2002) and evidence exists which shows an increase in the occurrence of toxic blooms since the $1980 \mathrm{~s}$ to the end of the $90 \mathrm{~s}$ (Oliveira, 1985; Vasconcelos et al., 1996; INTERREG-II, 2000). It is well known that cyanobacterial toxic blooms constitute a risk for health since they are accompanied by the production and release of toxins, responsible for animal and human intoxications (Billings, 1981; Carmichael, 1981; Codd and Poon, 1988). Among the toxic genera, Microcystis is the most frequently observed in the Guadiana River (Vasconcelos et al., 1996; Rocha et al., 2002) and MC-LR one of the most common toxins found in these water samples (Vasconcelos et al., 1996).

The understanding of the ecological causes that promote bloom formation in estuarine systems is particularly complicated due to their heterogeneous conditions, which exhibit strong gradients between their freshwater and marine zones. The turbidity produced by high suspended particulate matter concentrations, frequently limits primary productivity to surface waters and the salinity gradient can stress phytoplankton and bacterioplankton transported down the river (Goosen et al., 1999; Herman \& Heip, 1999). Freshwater cyanobacteria are not generally associated with estuarine environments because of their limited tolerance to salinity (Kirst, 1990). They can be adversely affected by high salinities during summer and autumn (Kurup et al., 1998), while lower water temperatures and light intensities, as well as higher freshwater flow rates during winter and spring, make the conditions sub-optimal for growing. In most of the estuaries higher densities have been linked to rainfall events transporting cyanobacteria from adjoining wetlands into the estuary, rather than to growth within the estuary (John, 1994). Conversely, toxic cyanobacteria in the Guadiana estuary are almost continuously present throughout the year (INTERREG-II, 2000; Rocha et al., 2002).

This work shows the results obtained in a study focused on the monitoring of physical and chemical and biological characteristics of the Guadiana estuary during the spring of 2002 and the new ongoing water control program. The main goals of the study were to assess their effects on $\mathrm{MC}$ concentrations along the estuary and to determine their levels in the environment in order to help the prevention of possible animal and human health problems. 


\section{MATERIAL AND METHODS}

\section{Sampling design}

Sampling stations were established along a longitudinal transect covering an area from South to North between Foz de Odeleite, Alcoutim (Sanlúcar de Guadiana in Spanish territory) and Mértola (Fig. 1). Alcoutim corresponds to the limit of the salt intrusion zone $(35 \mathrm{Km}$ from the mouth in Vila Real de Santo Antonio) and Mértola to the limit of the tidal influx $(60 \mathrm{Km}$ from the mouth). Samples were taken approximately every 15 days from March to May 2002 during neap tide periods. Field surveys were performed during high tide conditions $( \pm 2 \mathrm{~h})$. The aim was to collect samples when tidal velocities were lower, thus reducing the possibility of sample streaming, but with the highest level of salt intrusion for these tidal conditions.

\section{Field measurements}

Temperature, transparency of the water (turbidity) and salinity were measured in situ during field surveys. Temperature at the surface was determined with a WTW dissolved oxygen temperature meter Oxi 197 connected to a $40 \mathrm{~m}$ length WTW TA 197 sensor.

Salinity was determined with a refractometer and measured in practical salinity units (PSU).

Turbidity was determined by a Secchi disk and light extinction coefficient was calculated as recommended by Parsons et al. (1984) where $\mathrm{k}^{\prime}=1.4 / \mathrm{Ds}$, being $\mathrm{K}^{\prime}$ the extinction coefficient and Ds the depth of disk disappearance.

\section{Laboratory analysis}

Five L of cooled surface water samples were maintained in the dark during transportation to the laboratory (approximately $2 \mathrm{~h}$ ).

Water samples for nutrient quantification were filtered with $0.45 \mu \mathrm{m}$ Whatman acetate cellulose filters and frozen until analysis. Determinations for dissolved silica and orthophosphate concentrations in water were made

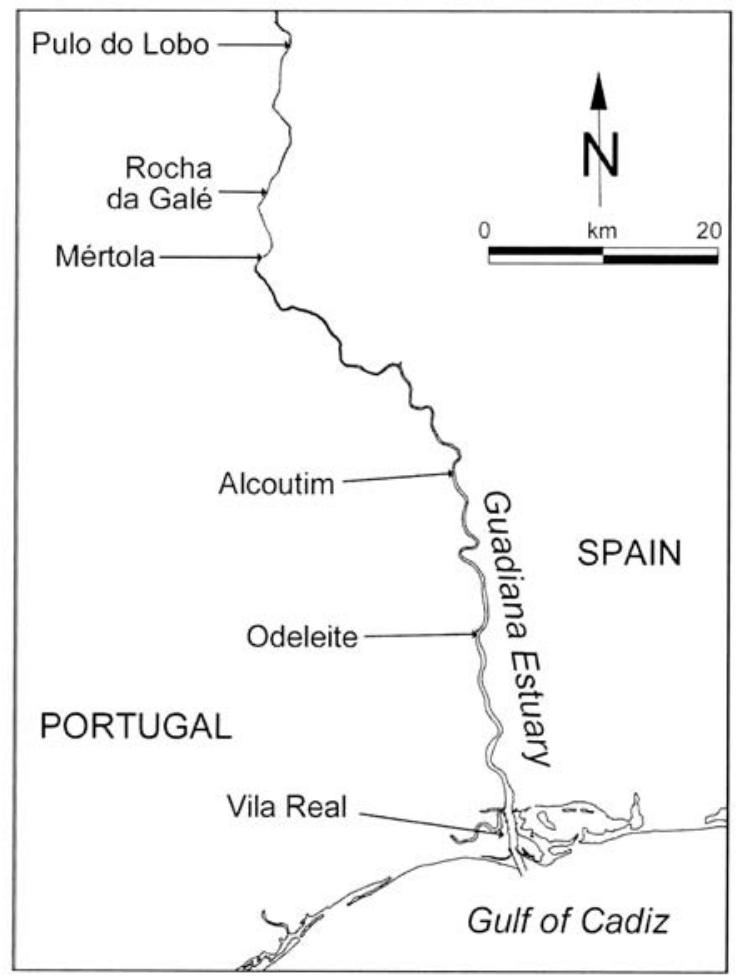

Figure 1. Location of Guadiana River and sampling stations in the Guadiana estuary. Mértola station is located upriver corresponding to the limit of tidal influx $(60 \mathrm{Km}$ from the mouth), followed from North to South for Alcoutim station, and finally Odeleite station. Alcoutim corresponds to the limit of salt intrusion zone $(35 \mathrm{Km}$ from the mouth in Vila Real de Santo Antonio). Localización del Río Guadiana y de las estaciones de muestreo en el estuario del Guadiana. La estación de Mértola está situada río arriba y se corresponde con el limite de influencia de las mareas $(60 \mathrm{Km}$ de distancia desde la desembocadura), seguida de Norte a Sur por la estación de Alcoutim, y finalmente la estación de Odeleite. Alcoutim se corresponde con el límite de influencia salina $(35 \mathrm{Km}$ desde la desembocadura en Vila Real de Santo Antonio).

spectrophotometrically following Parsons et al. (1984) protocols in triplicate. Nitrate analyses were made following the method of Granshoff $(1983 a, b)$, and at least in duplicate.

For chlorophyll $a$ determination $250 \mathrm{~mL}$ of water were filtered through Whatman GF/F filters. The filters were then submerged in acetone $90 \%$ and maintained in the dark at least overnight at $-20^{\circ} \mathrm{C}$. After centrifugation the supernatant was measured spectrophotometrically in the respective wavelengths according to the equa- 
tions of Parsons et al. (1984). Analyses were performed at least in duplicate.

Water samples for the enumeration of picophytoplankton and nanophytoplankton cells were preserved with glutaraldehyde $25 \%$ ( $2 \%$ final concentration) and maintained in the dark at $4^{\circ} \mathrm{C}$ until staining with proflavine. Stained samples were filtered through $0.45 \mu \mathrm{m}$ Micron Separations Inc. dark policarbonate filters disposed on $0.2 \mu \mathrm{m}$ Whatman cellulose acetate filters. Policarbonate filters were mounted on glass slides with immersion oil (Cargille type A). All preparations were made within $24 \mathrm{~h}$ after sampling and stored at $-10^{\circ} \mathrm{C}$ to minimize the loss of autofluorescence. A minimum of 20 random fields were counted at 600 to $1250 \mathrm{x}$ magnification with a Leica DM-LB epifluorescence microscope equipped with blue light illumination (Haas, 1982). Samples for the enumeration of micro-sized ( $>20 \mu \mathrm{m})$ diatoms and dinoflagellates were preserved with acid Lugol solution, sedimented in sedimentation chambers for 24 to $48 \mathrm{~h}$, and observed with a Wild inverted microscope (Utermohl, 1958). More than 100 cells of the most common taxa were counted. It is to be noted that the presence of large amounts of particulate matter in the samples interfered with phytoplankton cell counts.

The chromatographic analysis (HPLC) of MCs were performed in a Dionex ${ }^{\circledR}$ Summit ${ }^{\mathrm{TM}}$ equipment with photodiode array detector (PDA) and Chromeleon 6.3 software, using an Acclaim C18

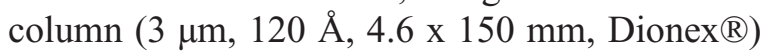
kept at $40^{\circ} \mathrm{C}$. Acetronitrile and Milli-Q water plus $0.05 \%(\mathrm{v} / \mathrm{v})$ TFA (trifluoroacetic acid) were used as mobile phase, starting at 25:75 and changing in a linear gradient to 55:45 final proportion after $30 \mathrm{~min}$. Chromatograms were monitored between 180 and $900 \mathrm{~nm}$, with main detection at $238 \mathrm{~nm}$. Purified MC-LR (Sigma ${ }^{\circledR}$ ) was used as standard, so the results were expressed in MC-LR equivalents (MC-LR Equiv.) per volume of sample.

For each case 1.5 to $2 \mathrm{~L}$ water sample were filtered through Whatman GF/F filters. The filters were frozen until extraction with $20 \mathrm{~mL}$ $80 \%(\mathrm{v} / \mathrm{v})$ methanol. As the particulate material bigger than $0.7 \mu \mathrm{m}$ was retained on the fil-
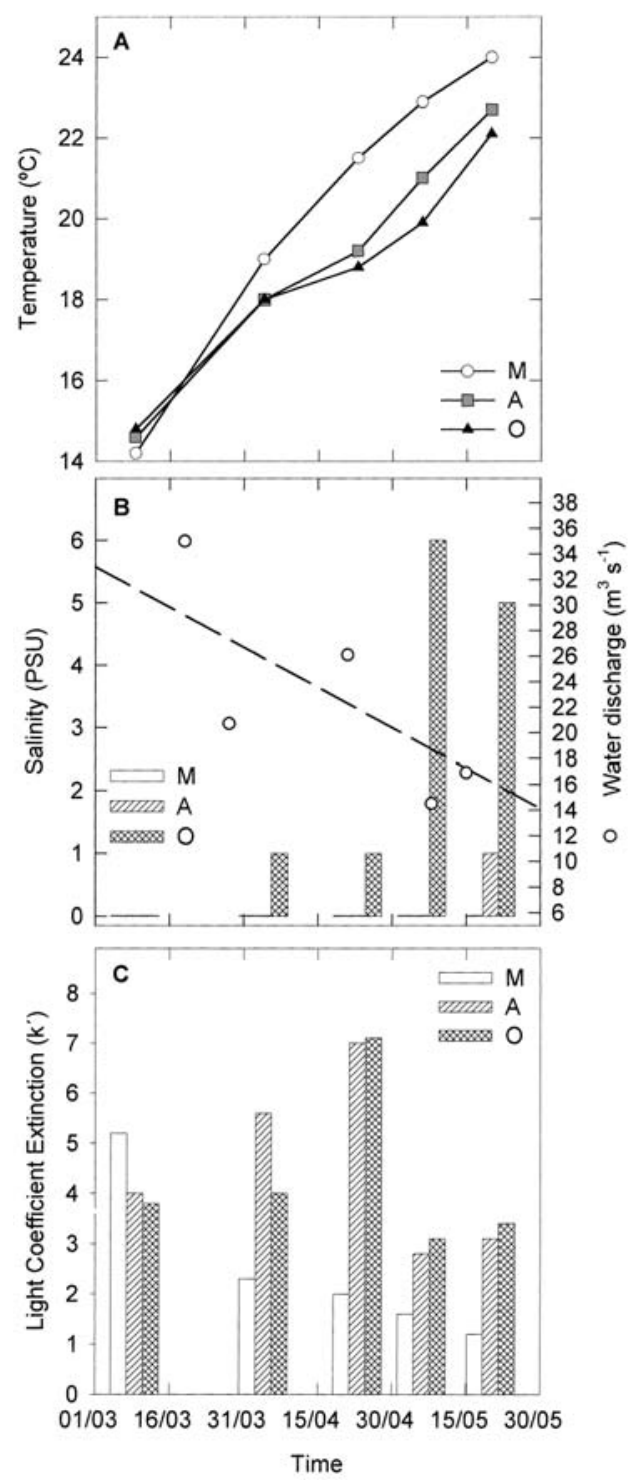

Figure 2. (A) Temperature $\left({ }^{\circ} \mathrm{C}\right)$, (B) salinity (PSU), and (C) turbidity $\left(\mathrm{k}^{\prime}\right.$, light coefficient extinction) values measured in situ during sampling surveys in 2002. Water discharge $\left(\mathrm{m}^{3} \cdot \mathrm{s}^{-1}\right)$ values were provided by SNIRH (Sistema Nacional de Informação de Recursos Hídricos de Ministerio do Ambiente) and dotted line was obtained from linear regression. M: Mértola station; A: Alcoutim station; O: Odeleite station. Valores de (A) temperatura $\left({ }^{\circ} \mathrm{C}\right)$, (B) salinidad (PSU), y (C) turbidez ( $k^{\prime}$, coeficiente de extinción de luz) medidos in situ durante las campañas de muestreo realizadas en el año 2002. Los valores de caudal $\left(\mathrm{m}^{3} \cdot \mathrm{s}^{-1}\right)$ fueron cedidos por el SNIRH (Sistema Nacional de Información de los Recursos Hídricos del Ministerio de Ambiente) y la línea punteada fue obtenida a partir de una regresión lineal. M: Estación de Mértola; A: Estación de Alcoutim; O: Estación de Odeleite. 
ter, the toxins extracted were those corresponding to the intracellular content plus those adsorbed to the matter in suspension. Extracts were then concentrated by rotatory evaporation, resuspended in $450 \mu \mathrm{L} 100 \%$ methanol and subsequently analyzed by HPLC.

\section{RESULTS}

The water temperature increased from March to late May as expected. In March lowest values were $14^{\circ} \mathrm{C}$ and in May the highest was $24^{\circ} \mathrm{C}$ (Fig. 2.A). While in late winter water temperature was colder from upriver to downriver, during spring the opposite occurred due to the effect of coastal waters. Water in Mértola showed higher temperatures than in Alcoutim, which in turn was higher than in Odeleite, creating a longitudinal temperature gradient during this season.

Salt intrusion was negligible in late winter in the reported stations but increased with the decrease in water discharge from March to the end of May, although never affecting the station at Mértola. As expected, maximum values were found in Odeleite (6.0 PSU) while Alcoutim showed an intermediate position with maximum values of 1.0 PSU (Fig 2.B).

The pattern of light penetration in the water column is shown in figure 2.C. The water in the selected stations showed high turbidity with Ds values between 20 and $105 \mathrm{~cm}$. The light coefficient extinction parameter $\left(\mathrm{k}^{\prime}\right)$ changed, as well as the other measured parameters, from late winter to spring. Turbidity was higher in March, and in Mértola than in Alcoutim, which was in turn higher than in Odeleite, probably due to the high freshwater discharge of winter months. Light penetration in the water column increased at Mértola station with the development of the spring season, and was deeper in Mértola than in Alcoutim, which was deeper than in Odeleite station, changing the whole longitudinal gradient (Fig. 2.C).

Table 1 shows dissolved nitrate, silicate and phosphorus concentrations and $\mathrm{N}: \mathrm{P}, \mathrm{Si}: \mathrm{N}$ and Si:P molar ratios at the three sampling stations. For all the nutrients, values in March were higher upriver in Mértola than in Alcoutim and this was

Table 1. Dissolved nitrate $(\mathrm{N})$, phosphate $(\mathrm{P})$ and silicate $(\mathrm{Si})$ concentrations $(\mu \mathrm{M})$ and N:P, Si:N and Si:P ratios found at selected sampling stations (Mértola, Alcoutim, Foz de Odeleite) during survey period. Results show the average \pm standard deviation. Concentraciones de nitrato (N), fosfato $(P)$ y silicato (Si) disuelto $(\mu M)$ y cocientes N:P, Si:N y Si:P encontrados en las estaciones seleccionadas (Mértola, Alcoutim, Odeleite) durante las campañas de muestreo. Los resultados muestran la media \pm desviación estándar.

\begin{tabular}{|c|c|c|c|c|c|c|}
\hline & $\mathbf{N}$ & $\mathbf{P}$ & Si & $\mathbf{N}: \mathbf{P}$ & Si:N & Si:P \\
\hline \multicolumn{7}{|l|}{ Mértola } \\
\hline 19 March & $45.3 \pm 1.6$ & $5.3 \pm 0.0$ & $150.7 \pm 4.6$ & 8.6 & 3.3 & 28.5 \\
\hline 04 April & $29.5 \pm 0.7$ & $3.3 \pm 0.0$ & $79.7 \pm 3.9$ & 9.0 & 2.7 & 24.3 \\
\hline 19 April & $61.5 \pm 3.3$ & $4.7 \pm 0.8$ & $87.6 \pm 15.3$ & 13.2 & 1.4 & 18.8 \\
\hline 06 May & $34.4 \pm 1.4$ & $3.6 \pm 0.3$ & $16.0 \pm 1.3$ & 9.6 & 0.5 & 4.5 \\
\hline 20 May & $28.1 \pm 0.7$ & $3.6 \pm 0.1$ & $42.8 \pm 5.4$ & 7.8 & 1.5 & 11.9 \\
\hline \multicolumn{7}{|l|}{ Alcoutim } \\
\hline 19 March & $35.5 \pm 0.4$ & $3.5 \pm 0.0$ & $103.7 \pm 2.9$ & 10.1 & 2.9 & 29.4 \\
\hline 04 April & $42.7 \pm 0.3$ & $4.0 \pm 0.0$ & $143.6 \pm 10.4$ & 10.6 & 3.4 & 35.7 \\
\hline 19 April & $46.8 \pm 1.1$ & $5.2 \pm 0.4$ & $74.9 \pm 4.8$ & 9.0 & 1.6 & 14.4 \\
\hline 06 May & $54.5 \pm 1.9$ & $4.3 \pm 0.1$ & $172.6 \pm 0.9$ & 12.7 & 3.2 & 40.3 \\
\hline 20 May & $35.8 \pm 0.9$ & $4.0 \pm 0.1$ & $133.9 \pm 2.3$ & 9.0 & 3.7 & 33.7 \\
\hline \multicolumn{7}{|l|}{ Odeleite } \\
\hline 19 March & $42.5 \pm 0.6$ & $2.6 \pm 0.0$ & $67.8 \pm 5.3$ & 16.4 & 1.6 & 26.2 \\
\hline 04 April & $46.3 \pm 0.5$ & $6.6 \pm 0.0$ & $144.1 \pm 8.5$ & 7.1 & 3.1 & 22.0 \\
\hline 19 April & $29.0 \pm 1.8$ & $4.1 \pm 0.1$ & $54.7 \pm 5.5$ & 7.1 & 1.9 & 13.5 \\
\hline 06 May & $7.7 \pm 0.7$ & $3.3 \pm 0.0$ & $161.1 \pm 1.3$ & 2.3 & 21.0 & 48.6 \\
\hline 20 May & $32.7 \pm 1.4$ & $4.1 \pm 0.1$ & $151.5 \pm 1.8$ & 7.9 & 4.6 & 36.7 \\
\hline
\end{tabular}




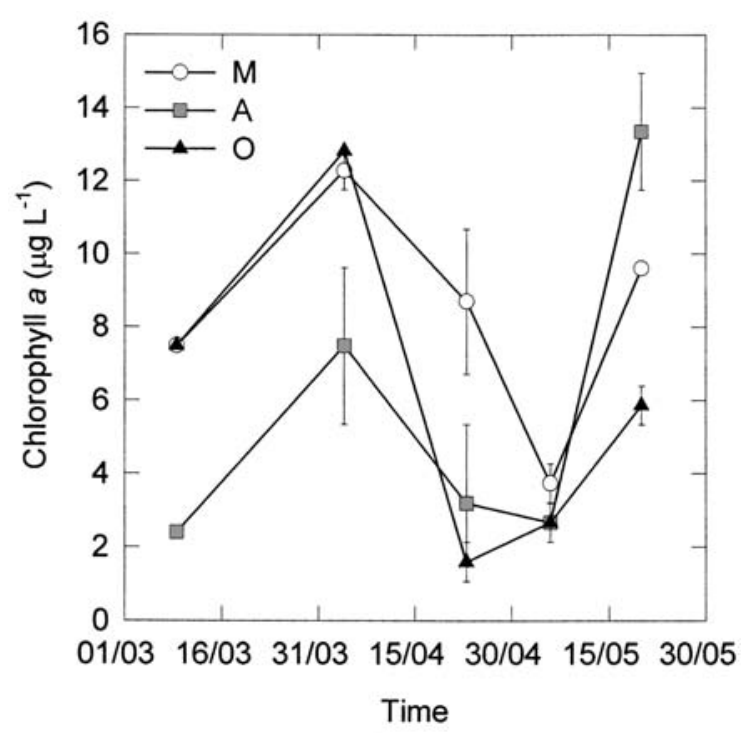

Figure 3. Chlorophyll $a$ content $\left(\mu \mathrm{g} \cdot \mathrm{L}^{-1}\right)$ from water samples collected during sampling surveys. M: Mértola station; A: Alcoutim station; O: Odeleite station. Contenido de clorofila a $\left(\mu g \cdot L^{-1}\right)$ de las muestras de agua recogidas durante las campañas de muestreo. M: Estación de Mértola; A: Estación de Alcoutim; O: Estación de Odeleite.

higher than in Odeleite. For silica concentrations, this gradient changed until the end of May decreasing progressively in Mértola station and tending to increase with similar patterns in Alcoutim and Odeleite. Dissolved silica concentrations were quite high with values between 172 and 16 $\mu \mathrm{M},(106 \pm 48 \mu \mathrm{M})$. Nitrate and phosphorus concentrations did not show marked differences between the stations. Molar ratios showed that nitrate was the limiting nutrient in almost all the stations for the whole of the sampling period (Table 1). Si:N and Si:P molar ratios tended to increase from upriver to downriver in late spring while N:P ratio tended to decrease (Table 1).

Chlorophyll $a$ concentration did not follow a general pattern with varying maximum values depending on the station. However, concentrations were higher in the beginning of April and at the end of May with maximum values close to 13 and $14 \mu \mathrm{g} \mathrm{L}^{-1}$, respectively (Fig 3).

The abundance and distribution of the main phytoplankton groups in the Guadiana estuary are shown in Fig. 4 (A, B, C). The cyanobacteria was the predominant group in Mértola station, almost
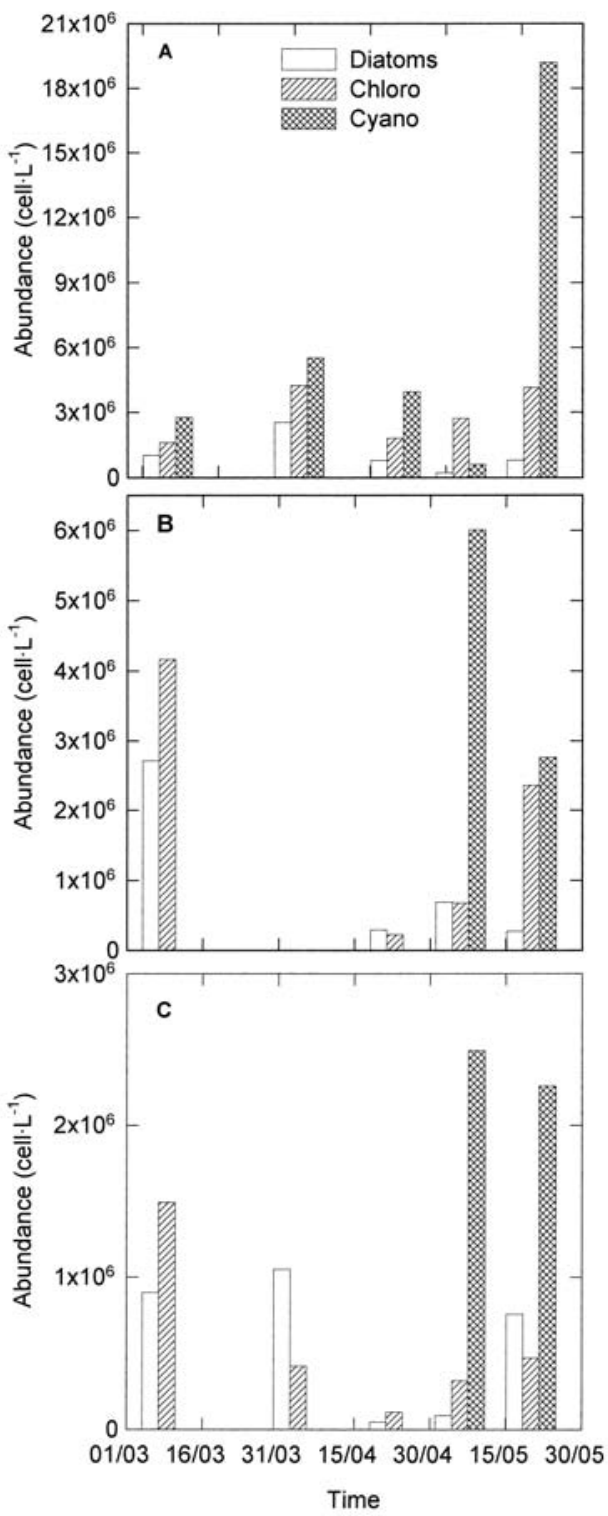

Figure 4. Abundance (cell $\left.\cdot \mathrm{L}^{-1}\right)$ of diatoms, chlorophytes and cyanobacteria in water samples collected during sampling surveys. A) Mértola station; B) Alcoutim station; C) Odeleite station. Abundancia $\left(\mathrm{cel} \cdot \mathrm{L}^{-1}\right)$ de diatomeas, clorofitas y cianobacterias en las muestras de agua recogidas durante las campañas de muestreo. A) Estación de Mértola; B) Estación de Alcoutim; C) Estación de Odeleite.

for the whole sampling period. The maximum value of $1.92 \cdot 10^{4}$ cell $\cdot \mathrm{mL}^{-1}$ was found at the end of May (Fig. 4.A). Alcoutim and Odeleite stations showed a different pattern, although similar bet- 
ween them, with chlorophytes being the more abundant group during winter time followed by diatoms. Chlorophyte and diatom abundance in these stations decreased during spring with increasing numbers of cyanophytes observed in late spring (Fig. 4 B, C). Microcystis was the more frequent and more abundant cyanobacteria in all three stations. Oscillatoria in winter samples and Gomphosphaeria in late spring were also observed in Mértola and Alcoutim stations. Between the chlorophyte genera, Scenedesmus, Pediastrum and Coelastrum were the most frequently observed, and between diatoms Cyclotella, Melosira and Coscinodiscus predominated.

In contrast to chlorophyll $a$ concentrations in the water column, the distribution of MC-LR content in the particulate material along the river presented a well defined longitudinal gradient with maximum values upriver in Mértola station, followed by values observed in Alcoutim station and finally those from the Odeleite station (Fig. 5). A relationship between chlorophyll values and $\mathrm{MC}$ content was not found. MC-LR content in the particulate material reached a maximum of $1.01 \mu \mathrm{g}$ MC-LR Equiv. $\mathrm{L}^{-1}$ during the beginning of May. Several peaks, which had a similar spectrum of absorption of MCs at $238 \mathrm{~nm}$, were observed at the HPLC chromatograms from Guadiana samples; at least five different variants were observed (including the variant MC-LR at some samples).

\section{DISCUSSION}

Results obtained in this study showed the development of a longitudinal gradient in MC content in particulate material along the Guadiana estuary during spring of 2002. This gradient was related to the existence of temperature, turbidity, salinity and nutritional longitudinal gradients which regulated the growth of toxic cyanobacteria.

Although behavior of different cyanobacterial taxa in nature is not homogeneous due to their different ecophysiological properties, it is well established that in general, they attain maximum growth rates at temperatures higher than for

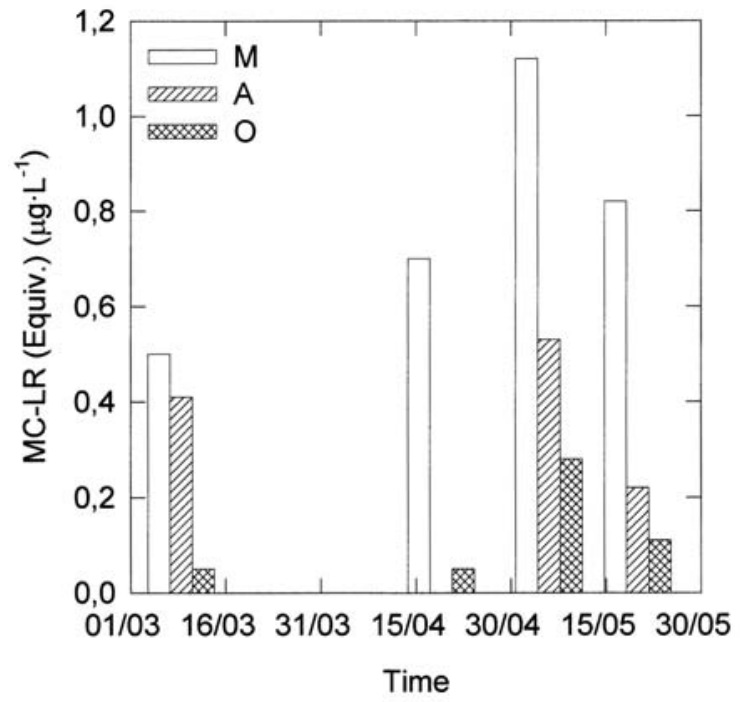

Figure 5. Microcystin-LR equivalents $\left(\mu \mathrm{g} \cdot \mathrm{L}^{-1}\right)$ content in particulate material obtained from water samples collected during sampling surveys. M: Mértola station; A: Alcoutim station; O: Odeleite station. Contenido de equivalentes de microcistina$L R\left(\mu g \cdot L^{-1}\right)$ en material particulado obtenidos a partir de las muestras de agua recogidas durante las campañas de muestreo. M: Estación de Mértola; A: Estación de Alcoutim; O: Estación de Odeleite.

green algae and diatoms (Chorus \& Bartram, 1999). This fact could explain why in most temperate and boreal water bodies cyanobacteria bloom during summer. Moreover, optimum temperature for hepatotoxin production by Microcystis aeruginosa, one of the dominant toxic species in the Guadiana river (Vasconcelos et al., 1996) and Oscillatoria agardhii varies from $18^{\circ} \mathrm{C}$ to $25^{\circ} \mathrm{C}$ (Watanabe \& Oishi, 1985; Codd \& Poon, 1988; Sivonen, 1990). In the Guadiana estuary the high temperatures observed at Mértola station followed by those observed in Alcoutim and finally Odeleite station, are progressively closer to these favorable conditions promoting the development of the gradient in MC concentrations (Fig 1.A).

Salinity has been found to be another important factor influencing the production of cyanotoxins (Blackburn et al., 1996; Hobson et al., 1999), although many species are also capable of growth and bloom over a wide range of salinities (Reed \& Stewart, 1988) from freshwater, 
in lakes and rivers, transitional brackish environments, such as estuaries, to oceanic waters and even in hypersaline lakes (Fay, 1983). Analysis of natural and cultured $M$. aeruginosa samples collected at different salinities in the Patos Lagoon (salinity varying from 0 to 10 PSU) demonstrated that growth rate, glutamine synthetase activity, photosynthetic rate and intracellular MC concentration decreased as salinity increased (Salomon et al., 2001). Furthermore, recent results based on a three dimensional modeling of a Microcystis bloom event in a western Australian estuary provided evidence that salinity and temperature were the primary factors controlling the growth of Microcystis during the period of interest (Robson \& Hamilton, 2002). Our results are in good agreement with those previous studies (Salomon et al., 2001; Robson \& Hamilton, 2002) that the inhibitory role of salinity on the $\mathrm{MC}$ content can be also responsible for the MC gradient observed in the Guadiana estuary.

The study of the effect of light intensity on toxin production has resulted in several conclusions. Codd \& Poon (1988) noticed that light had no, or only slight, effect on toxicity of $M$. aeruginosa. Conversely, Watanabe \& Oishi (1985) and Utkilen \& Gjølme (1992) observed a change in toxin production by the same species induced by light intensity. Other species such as Oscillatoria agardhii produced the highest toxin levels at low light intensities (12-24 $\mu \mathrm{mol} \cdot \mathrm{m}^{-2} \cdot \mathrm{s}^{-1}$; Sivonen, 1990) while the effect of light on three different strains of Nodularia did not produce significant differences on nodularin production (Lehtimäki et al., 1994). However, independent to the effects of light on toxin production, cyanobacteria need light for growth and one of the characteristics that provide a significant advantage to gas-vacuolate cyanobacteria, such as Microcystis, Anabaena, or Aphanizomenon, over other microalgae is the buoyancy and the capability for its regulation (Oliver \& Ganf, 2000). In turbid waters, such as in the Guadiana estuary, the depth of light penetration is low (Fig 2.C), so light collection for photosynthesis is limited to a few centimeters at the surface.
Furthermore, this same capability decreases cyanobacteria sinking rates comparing with other phytoplanktonic groups. They can also develop large aggregates (colonies) of coccoid cells or filaments which are not homogeneously distributed over the water body. Differences in densities between colonies and water, and colony size allow the cell aggregates to regulate buoyancy in the water column to obtain optimal conditions for growth. However a prerequisite is that the water body is not too turbulent (Chorus \& Bartram, 1999). As it could be expected, highly turbid stations such as Alcoutim and Odeleite stations could give advantage to gasvacuolated cyanobacteria over other microalgae compared with less turbid waters in Mértola. However, water in Alcoutim is commonly quite turbulent, probably due to the physical and chemical mechanisms derived from the transition between seawater and freshwater (INTERREGII, 2000; Herman and Heip, 1999) and water in Odeleite was affected by salinity intrusion, negatively regulating growth of MC producers such as Microcystis spp.

Recent studies, before the Alqueva dam construction, have demonstrated that the availability of dissolved nutrients in the medium played an essential role in phytoplankton bloom succession throughout the year in the Guadiana estuary, being the silica limitation one of the principal factors responsible for the development of cyanobacteria blooms (Rocha et al., 2002). The high winter loads of nitrogen and phosphorus lead to the depletion of silicate $(<0.2 \mu \mathrm{M})$ during an early spring diatom bloom. Then, low monthly discharge rates during spring and summer provided an environment with low $\mathrm{Si}: \mathrm{N}$ and $\mathrm{N}: \mathrm{P}$ relatively availability, which coupled with the high water column temperature $\left(>21^{\circ} \mathrm{C}\right)$ seemed to favour the dominance of cyanobacteria over chlorophytes during summer (Rocha et al., 2002).

During late winter and spring of 2002 no diatom bloom was observed (Fig. 4). Phytoplankton composition was dominated by cyanobacteria in the freshwater station (Fig. 4.A) and by chlorophytes during late winter, followed by cyano- 
bacteria in late spring downriver in Alcoutim and Odeleite stations (Fig. 4.B,C). However, the predominance of cyanobacteria is also related with the presence of low N:P ratios (Table 1). Taking as reference the standard molar ratios between $\mathrm{N}, \mathrm{Si}$ and $\mathrm{P}$ for marine diatom biomass growth (Si:N:P= 16:16:1, Redfield et al., 1963; Brzezinski, 1985), relative availability of nitrate was limiting for growth during the sampling period. Previous results have reported that freshwater cyanobacteria and chlorophytes have relatively low $\mathrm{P}$ requirements $\left(\mathrm{K}_{\mathrm{m}}=0.03-1.89\right.$ $\mu \mathrm{M}$, Tilman et al., 1982), and phosphorus was available above these concentrations during the sampling period. However, chlorophytes have been described as the poorest $\mathrm{N}$ competitors although they dominate cyanobacteria in $\mathrm{P}$ competition (Sommer, 1999).

Silica concentration data from 2002 are extremely high compared with those obtained in 1997 (Rocha et al., 2002). Moreover, values do not seem to follow the expected pattern with marked peaks at all stations during winter flushing of the estuary by freshwater discharge and with low concentrations $(<5 \mu \mathrm{M})$ during spring-fall period. On the other hand, MC concentrations in particulate material are also higher compared with previously reported studies where toxin content attained maximum values of $50 \mathrm{ng} \cdot \mathrm{L}^{-1}$ in April (INTERREG-II, 2000). High availability of silica in the estuary in regard to the other principal nutrients was able to promote diatom predominance before the sampling period, decreasing nitrate concentration and altering the previously observed pattern of successive blooms of different phytoplankton assemblages. Then, Mycrocystis cells capable of regulating buoyancy in turbid waters could have an advantage over diatoms and chlorophytes, dominating upriver in the freshwater area and creating a longitudinal gradient in $\mathrm{MC}$ content regulated by temperature and salinity.

Regulation of rivers by damming as well as eutrophication in river basins has substantially reduced dissolved silica loads in the Black Sea and the Baltic Sea (CEC, 2001). While removal of nitrates and phosphates in lakes and reser- voirs can be compensated for by the anthropogenic inputs in the drainage basins, no such compensation occurs for silicates. Reservoirs act as silica traps, but the main processes responsible for the reservoir retention (biological $v s$. physicochemical) are not fully clear. The fact that silica concentrations presented in this report were higher than those observed before dam construction began could be related with factors that implicate the construction process itself, such as soil displacement or inundation of previously uncovered areas. Thus, 2002 could be considered as a transition state with respect to silicate and MC concentrations in the estuary.

These results were part of a one year project, so further results are needed to obtain more conclusive considerations about the state of water quality in the Guadiana River. Moreover, the development of long term environmental monitoring is also necessary to assess on-going alterations in the ecohydrological state of the river and estuary as well as possible effects on coastal biogeochemical cycles and food web structure.

\section{ACKNOWLEDGEMENTS}

The authors would like to thank Dr. Carlos Rocha for his suggestions, Dr. Neale Ruane for English corrections and Dr. Ramón Gonzalez for providing the Guadiana estuary map. The Portuguese National Foundation for Science and Technology (FCT) provided funding for C.S. and A.M. through postdoctoral fellowships.

\section{REFERENCES}

BILLINGS, W. H., 1981. Water-associated human illness in Northeast Pennsylvania and its suspected association with blue-green algae blooms. In: The water environment: Algal Toxins and Health. W.W. Carmichael (ed.).:243-255. Plenum Press, New York.

BLACKBURN, S. I., M. A. McCAUSLAND, C. J. S. BOLCH, S. J. NEWMAN \& G. J. JONES. 1996. Effect of salinity on growth and toxin production in cultures of the bloom-forming cyanobacterium 
Nodularia spumigera from Australian waters. Phycologia, 36(6): 511-522.

BRZEZINSKI, M. A. 1985. The Si:C:N ratio of marine diatoms: interespecific variability and the effect of some environmental variables. J. Phycol., 21: 347-357.

CABEÇADAS, G. \& M. J. BROGUEIRA. 1981. Notas sobre a qualidade da água do Rio Guadiana. Internal report $\mathrm{N}^{\circ}$ 42. IPIMAR, National Institute for Fisheries and Marine Research. Lisbon.

CARMICHAEL, W. W. 1981. Freshwater blue-green algae (cyanobacteria) toxins- a review. In: The water environment: Algal Toxins and Health. W.W. Carmichael (ed.).: 1-13. Plenum Press, New York.

COMISSION OF THE EUROPEAN COMMUNITIES (CEC). 2001. Environmental cooperation in the Danube-Black Sea region. Brussels.

CODD, G. A. \& G. K. POON. 1988. Cyanobacterial toxins. In: Biochemistry of the algae and cyanobacteria. L. J. Rogers \& J. R. Gallon (eds.). Proc. Phytochem. Soc. Europe. 28: 283-296. Oxford University Press, Oxford.

CHORUS, I. \& J. BARTRAM. 1999. Toxic cyanobacteria in water- a guide to their public health consequences, monitoring and management. Published on behalf of the World Health Organization (WHO). E \& FN Spon, London.

EUROPEAN ENVIRONMENTAL AGENCY. 2000. Eutrophycation. In: Environmental signals 2000. Environmental assessment report, 6: 82-90.

FAY, P. 1983. The blue greens. Studies in Biology $\mathrm{N}^{\circ}$ 160. Edward Arnold, London.

GOOSEN N. K., J. KROMKAMP, J. PEENE, P. VAN RIJSWIJK \& P. VAN BREUGEL. 1999. Bacterial and phytoplankton production in the maximum turbidity zone of the three European estuaries: the Elbe, Westerschelde and Gironde. J. Mar. Sys., 22: 151-171.

GRANSHOFF, K. 1983a. Determination of nitrate. In: Methods of seawater analysis. $2^{a} E d$. K. Granshoff, M. Ehrhardt \& K. Kremling (eds.): 139-142. Verlag Chemie.

GRANSHOFF, K. 1983b. Determination of nitrate. In: Methods of seawater analysis. $2^{a} E d$. K. Granshoff, M. Ehrhardt \& K. Kremling (eds.): 143-150. Verlag Chemie.

HAAS, L. W. 1982. Improved epifluorescence microscopy for observing planktonic microorganisms. Ann. Inst. Oceanogr., Paris, 58 (S): 261-266.

HERMAN P. M. J., \& C. H. R. HEIP. 1999.
Biogeochemistry of the MAximum TURbidity Zone of Estuaries (MATURE): some conclusions. J. Mar. Sys., 22: 89-104.

HOBSON, P., M. BURCH \& H. J. FALLOWFIELD. 1999. Effect of total dissolved solids and irradiance on growth and toxin production by Nodularia spumigera. J. Appl. Phycol., 11: 551-558.

INTERREG-II, 2000. Estudo dos blooms de cianobactérias associados a variações de caudal no Rio Guadiana. Final report University of Algarve, Faro. 59 pp.

JOHN, J. 1994. Eutrophycation in the Swan River Estuary, Western Australia and the management strategy. In: Global Wetlands: Old World and New. W. J. Mitsch (ed.): 749-757. Elsevier.

KIRST G. O. 1990. Salinity tolerance of eukariotic marine algae. Ann. Rev. Plant Physiol. Plant Mol. Biol., 41: 21-53.

KURUP, R., D. P. HAMILTON \& J. C. PATTERSON. 1998. Modelling the effects of the seasonal flow variations on the position of a salt wedge in a microtidal estuary. Estuarine Coastal Shelf Sci., 47: 121-208.

LEHTIMÄKI, J., K. SIVONEN, R. LUUKKAINEN \& S. I. NIEMELA. 1994. The effects of incubation time, temperature, light, salinity and phosphorus on growth and hepatotoxin production by Nodularia strains. Arch. Hydrobiol., 130 (3): 269-282.

OFFICER, C. B. \& J. H. RYTHER. 1980. The possible importance of silicon in marine eutrophycation. Mar. Ecol. Prog. Ser., 3: 83-91.

OLIVEIRA, M. R. L. 1985. Relatório dos estudos biológicos realizados no Rio Guadiana e na esta estação de tratamento de águas da Vila de Mértola. Internal report $\mathrm{N}^{\mathrm{o}} 103$, IPIMAR, National Institute for Fisheries and Marine Research. Lisbon. Portugal.

OLIVER, R. L. \& G. G. GANF. 2000. Freshwater blooms. In: The ecology of cyanobacteria. B. A. Whitton \& M. Potts (eds.). Kluver Academic Publishers. 6: 149-193.

PARSONS, T. R., Y. MAITA \& C. M. LALLI. 1984. A manual of chemical and biological methods for seawater analysis. London: Pergamon Press.

REDFIELD, A. C., B. H. KETCHUM \& F. A. RICHARDS. 1963. The influence of organisms in the composition of the seawater. In: The sea Vol II. M. N. Hill (ed.): 26-77.

REED, R. H. \& W. D. P. STEWART. 1988. The responses of cyanobacteria to salt stress. In: Biochemistry of the algae and cyanobacteria. L. J. 
Rogers \& J. R. Gallon (eds). 12: 217-231. Clarendon Press, Oxford.

ROBSON, B. J. \& D. P. HAMILTON. 2002. Three dimensional modelling of a Microcystis bloom event in a Western Australian estuary. Proceedings of the International Environmental Modelling and Software Society, 491-496.

ROCHA, C., H. GALVÃO \& A. BARBOSA. 2002. Role of transient silicon limitation in the development of cyanobacteria blooms in the Guadiana estuary, south-western Iberia. Mar. Ecol. Prog. Ser., 228: 35-45.

ROSENBERG, D. M., 2000. Global-scale environmental effects of hydrological alterations. BioScience (special issue devoted to hydrological alterations), 1-9.

RYTHER, J. H. \& C. B. OFFICER. 1981. Impact of nutrient enrichment on water uses. In: Estuaries and nutrients. B. J. Neilson \& L. E. Cronin (eds): 247-261. Humana Press, Clifton, USA.

SALOMON, P. S., J. S. YUNES, A. MATTHIENSEN \& G. A. CODD. 2001. Does salinity affect the toxin content of an estuarine strain of Microcystis aeruginosa?. In: Mycotoxins and phycotoxins in perspective at the turn of the millenium. W. J. de Koe, R. A. Samson, H. P. van Egmond, J. Gilbert \& M. Sabino (eds). Proceedings of the $\mathrm{X}^{\text {th }}$ International IUPAC Symposium on Mycotoxins and Phycotoxins, Guarujá, Brasil: 537-548.
SIVONEN, K. 1990. Effects of light, temperature, nitrate, orthophosphate and bacteria on growth and hepatotoxin production by Oscillatoria agardhii strains. Appl. Environ. Microbiol., 56: 26582666.

SOMMER, U. 1999. A comment on the proper use of nutrient ratios in microalgal ecology. Arch. Hidrobiol., 146(1): 23-35.

TILMAN, D., S. S. KILHAM \& P. KILHAM. 1982. Phytoplankton community ecology: the role of limiting nutrients. Ann. Rev. Ecol. Systematics, 13: 349-372.

UTKILEN, H. \& N. GJØLME. 1992. Toxin production by Microcystis aeruginosa as a function of light in continuous cultures and its ecological significance. Appl. Environ. Microbiol., 58: 13211325.

UTERMOHL, H. 1958. Zur vervollkommung der quantitativen phytoplankton-methodik. Mitt. Int. Verein. Theor. Limnol., 9: 1-38.

VASCONCELOS, V. M., K. SIVONEN, W. R. EVANS, W. W. CARMICHAEL \& $\mathrm{M}$. NAMIKOSHI. 1996. Hepatotoxic microcystin diversity in cyanobacterial blooms collected in Portuguese freshwaters. Wat. Res., 30: 2377-2384.

WATANABE, M. F. \& S. OISHI. 1985. Effects of environmental factors on toxicity of a cyanobacterium (Microcystis aeruginosa) under culture conditions. Appl. Environ. Microbiol., 49:1342-1344. 
